\title{
Analysis of the Advantages and Disadvantages on the Application of the Idea of Happy Physical Education in College Physical Education Teaching
}

\author{
Jianchun Chen ${ }^{1}$ \\ ${ }^{1}$ Qingdao University of Science and Technology, Qingdao, China \\ Correspondence: Jianchun Chen, Qingdao University of Science and Technology, Qingdao 266061, China. \\ E-mail: baijuan@qust.edu.cn
}

Received: June 25, 2013 Accepted: July 9, 2013 Online Published: August 1, 2013

doi:10.5539/ass.v9n10p207 URL: http://dx.doi.org/10.5539/ass.v9n10p207

\begin{abstract}
College physical education is one of the important contents in promoting the college students' quality education. Improving teaching quality and building up the students' physical quality have become the problems that the society is concerned. Through practices, the application of the idea of happy physical education can not only improve teaching quality effectively but also improve the students' physical conditions greatly. It not only has some advantages but also has some limitations. How to balance their relationships is one of the primary research contents in college physical education teaching.
\end{abstract}

Keywords: happy physical education, college physical education teaching, teaching quality

\section{Introduction}

College physical education teaching plays an important part in the present quality education. The traditional physical education teaching is characterized in that students are taught passively in order to achieve the requirements of examinations. Because of the spreading of the idea of happy physical education, physical education teaching in China is substantially influenced, especially the college physical education teaching. In colleges, the audience of physical education teaching is college students whose learning and life are very diverse. As a result, the idea of happy physical education is more suitable for them. This paper will analyses the advantages and disadvantages expressed in the idea of happy physical education combined with the college physical education teaching with the expectation to provide a favorable theoretical foundation, change the traditional misunderstanding to physical education teaching and achieve the innovation to physical education teaching.

\section{The Idea of Happy Physical Education}

The idea of happy physical education was born in 1960s and 1970s. Since the middle of the 1980s, with the starting of the physical education reform in schools, happy physical education was very popular in China and this idea spread speedily. The idea of happy physical education had substantial influence to China. The idea of happy physical education is defined as from the perspective of emotion, attaching great importance to the education of love and stressing interest in learning and creative learning. This idea takes physical exercise and emotion not only as the teaching methods but also as the direct goal and purpose, which will benefit the physical ability and ideal personality of students. Here "happy" is for the motion, but it does not exclude physical exercise of students. Furthermore, students are required to be persistent and work hard to strengthen physical fitness and form a scientific way of body-buildup which is suitable for oneself. Therefore, the idea of happy physical education is oriented in the life physical education and harmonious development of personality; put the relationship of students and sports on a right level, help to view and understand the nature of physical education and its importance to students in order to enable physical education to be an indispensable part of life.

Implementing happy physical education aims at improving teaching quality and accelerating the physical capability and comprehensive mental health of college students. Happiness is contained in physical education and it is specific and objective. Students are committed to work hard and be persistent to obtain the pleasure, which is the true happiness. Teachers are committed to search for the natural pleasure in the text books and extract the happiness to coordinate them with teaching goals and enable teaching to be full of interest. At the 
same time, students can experience happiness and teachers can complete teaching tasks so as to improve the pleasure and capability of enjoying sports.

\section{The Scientific Foundation of Happy Physical Education}

The theory and practice of happy physical education is very complete. Its generating is based on many researches and achievements of other disciplines.

\subsection{The Philosophical Foundation of Happy Physical Education}

The philosophical foundation of happy physical education is the theory about people addressed by Max who attached great importance to people's value, personality and dominant position. Furthermore, he stressed the development of people, pointing that "everyone's free development is the condition of all the people's progress". These theories are the foundation of happy physical education. The nature of happy physical education is to admit the difference of students, respect the difference of students and the personality of students, inspire and motivate the activeness and subjectivity of students and stress that students are the subject of learning in order to achieve the purposes of improving physical strength, developing personality and cultivating moral characters.

\subsection{The Psychological Foundation of Happy Physical Education}

According to the researchers, people's psychological system comprises cognition system and emotion system. From the perspective of psychology, after experiencing joy and pleasure from the physical education, students will have the motive to be engaged with physical education and truly improve the effect of physical education learning. For example, students who have a taste for basketball will pay attention to the information about basketball in spare time. When they are free, they will play basketball to enjoy and after much exercises, their capability to play basketball will be improved. To the contrary, if a student does not like basketball, he will surely not engage in playing basketball in free time.

\subsection{The Physiological Foundation of Happy Physical Education}

According to modern physiology, people's different emotional experience will bring in a series of physiological changes inside the body. When the outside stimuli can maintain, expand and develop the original motive, people will generate positive experience. After experiencing joy and pleasure from the physical education, students will have the motive to be engaged with physical education. If they have strong motives, they will have great interest. So the effect of physical education learning will be truly improved. For example, if a student has experienced the victory in a relay race, he would take an active part in another relay race.

\subsection{The Game Theory Foundation of Happy Physical Education}

Humanity's greatest pleasure is doing what they love. The motive of students engaged in sports is originated from the demand for sports and the pursuit to pleasure in doing sports. The achievement of happy physical education depends on whether the sports can satisfy the demands of students. Games are of great importance to people, which are closely related with consciousness. Further, the results of games are uncertain and unknown, so that games are very popular and charming. In education, the tug-of-war between students can improve the enthusiasm of activities and students can get practice from taking part in them. The basic theories of games are the foundation of physical education.

\section{The Advantages of the Combination of Happy Physical Education and College Physical Education}

1) The traditional sports teaching theory overemphasizes the dominant position of teachers and ignores the position of students. What is more, according to the traditional teaching theory, students are only the passive object and students are usually passively taught. Based on the idea of happy physical education teaching, the dominant position of students is highly stressed. It highlights the orientation of students, pays attention to students' emotions and bodies and inspires students' interest. At the same time, it helps to strengthen mutual understanding of teachers and students, so that teachers can better understand the demands of students and check whether the teaching can inspire the interest and hobbies of students or not. Only by this, can the teaching be improved. Therefore, in many colleges, sports elective courses are offered to students to meet different demands of students. At the same time, Department of Education also proposes the same requirement that every student have right to master one or two sports programs to study. So the distinct features are indicated from the college physical education. With subjective dynamics, students can learn more, education can be performed easily, and the idea of happy physical education can be better carried out.

2) In teaching structure, happy physical education emphasizes a three dimensional structure of knowledge, emotion and physical development. Therefore, college physical education teaching breaks the traditional mode of simple and narrow teaching goal and ignores the development of mental health and psychological quality of 
students so that students can not apply to practical competition and the form of teaching is too formal and simple. However, happy physical education can help to transform the knowledge and skill to physical capability. In the whole learning process, the emotional system of students is involved and through a vehicle of internal motive, happy physical education is achieved. It is the joy and pleasure that students obtain that can inspire the motive of students to be engaged in physical education and the good teaching can be achieved. In the organizing of teaching, the rigorous classroom discipline and the lively classroom atmosphere should be combined and the multidirectional communication of information and the optimization of teaching environment should also be achieved. For this reason, most colleges are favor of the usage of multimedia course wares enabling students to have to have new knowledge and new information and at the same time, students in a group can make study plans, with discuss with each other and evaluate with each other. Hence, students can experience the harmonious human relationship. For example, students who like table tennis form a group and students who are favor of basketball form a group in order to improve the teaching effect.

3) Happy physical education is very particular to the number of the class, court and equipment. For the arrangements of court and equipment are the preconditions of inspiring the motive of students and establishing a happy atmosphere. At present, stadiums and gymnasiums are well equipped which will lay a solid foundation for the implementing of happy physical education. For this reason, PE teachers are better to seize the psychological characteristics of college students, fully take advantages of the courts and equipment and attract their attention to participating in the activities. While meeting the interest of students, establishing their lifelong-sports consciousness is also of great importance.

4) For modern college students, learning to communicate with others and strengthening their social communication ability is very important to quality education and also a new demand of modern society. Physical education as an education form is a vital method to strengthen the social ability of students. Happy physical education pays great attention to establish a harmonious human relationship, in which the teacher-student relation is playing the role of medium. Meanwhile, the student-student relation is also significant, which is an indispensible factor in teaching. Through physical education, students have the opportunity to learn how to communicate, how to recognize competition and how to succeed through hardworking and communicating. Hence, this is also an advantage of happy physical education in college physical education teaching.

5) In the new period, the physical education teaching requires that college students should develop an idea of "lifelong spot". At the same time, many colleges also hold various colorful festivals of sports with featuring different styles and contents in order to meet the demands of students' cultural requirements. The idea of happy physical education aims to emphasizing the development of physical ability of students. It not only requires students to learn and master sports techniques but also pays much attention to develop students' ability of self-study, self-evaluation and self-practice. This is also an indispensable process which will lay a solid foundation for lifelong sports. In physical education teaching process, happy physical education takes games as the main method, interest as the main body and brings laughter to classes. It further emphasizes the personality development of college students to enable students to learn happily, to learn with interest and to learn fruitfully. No interest, no happiness. However, it is the physical teachers who can inspire and guide the interest of students. Only managing to improve the learning interest of college students, ca college students benefit from it. In this way, happiness can be completely achieved.

\section{The Disadvantages of the Combination of Happy Physical Education and College Physical Education}

Happy physical education, to some extent, has its disadvantages. Some people only regard happy physical education as laughing, joy and interest or take happy physical education as the teaching goal superficially. And students can choose the teaching contents by themselves. If the teaching contents can satisfy students' interest, then the happy physical education can be realized. For example, when Japan delegate took part in the school workshop organized by both Japan and China, the representative of Japan held that "the less teaches interfere, the better the teaching effect is". But this is not the real intention of happy physical education. Some other people hold that the goal of happy physical education is to pursue pleasure. For happy physical education, some people take it too literally; as a result, it brings in many misunderstandings in China. Many people think happy physical education is to satisfy students' interest, which is inadvisable.

1) Happy physical education emphasizes active thinking, active exploration, self-observation and self-analyzing to form one's own method and scientifically do exercises. But for the systematic teaching in college physical education, it prolongs teaching time and delays the teaching progress. Owing to the time increasing in exploration, improving and mastering sports technique is unavoidably influenced. Breaking the idea of centering on sports technique teaching is not equal to completely negate it. The thought that if sports technique teaching is 
not the center, then the entertainment is the center is very lopsided. For no matter the physical education how to reform, the physical exercise is indispensable and all physical exercises are involved with sports techniques; as a result, happy physical education cannot live without sports techniques. Highlighting happiness does not mean completely denying criticizing and education. Happiness and physical education are not opposed. Otherwise, the idea of happy physical education teaching will take a wrong direction. In this way, the idea of happy physical education is totally distorted.

2) In physical education teaching, teaching should be well organized and arranged. To the contrary, the teaching quality cannot be improved and exercises cannot be worked out, which will bring negative impact on teaching order and environment. Some physical education teachers wrongly regard the "happiness" as meeting personal demand of students, centering on students and playing games. And some other teachers overemphasize the dominant position of students and ignore the position of teachers, highlight the cultivation of interest and ignore the cultivation of good volitional qualities and experience of hard physical practice. What is more, college students are in the preliminary formation period of worldview; therefore, their realization and expectation are not stable, which determines that they need the right guidance and instruction. Hence, happy physical education should be carried under the guidance of teachers, with happiness containing in physical education teaching. It should be known that the idea of happy physical education teaching is the combination and integration of both "happiness" and "sports".

3) Because of the strong flexibility of happy physical education, some state-compiled textbooks cannot be suitable for the content and form of teaching, which needs teachers to promptly adjust the content and form of textbooks and self-develops new textbooks in spare time. As a result, they will have little time to prepare for class and cannot focus on teaching, which impacts the development of teaching and teaching effect. In fact, according to happy physical education, students are not committed to do a perfect action. For those who have a strong interest and ability, physical education teachers should take action to improve them and inspire their potential. The happiness in happy physical education means a kind of excitement after their sports techniques are lifted, a cheerful mood after learning knowledge and a sense of success after overcoming difficulties.

\section{Conclusions}

Happy physical education in college physical education teaching has both advantages and disadvantages. How to handle with these advantages and disadvantages is an important problem facing all physical teachers. The application of happy physical education can help students to do exercises by themselves, cultivate their ability of exploration, inspire their subjective spirit of creation, teach them to communicate with others, cultivate their quality of unity and hardworking and bring them happiness through struggling. But physical teachers should take advantages of the idea of happy physical education, inspire students' interest, create a better environment for students, meet their practical demands and wishes and better combine "happy teaching" with "happy learning" so as to improve teaching effect and express the education function of physical education. For this, happy physical education can better serve the quality education and develop students' overall quality to develop college physical education teaching scientifically, orderly and healthily and lay a solid foundation for establishing a lifelong sports consciousness.

\section{References}

Bai, D. B., \& Chen, X. Y. (1999). A discussion of the application of the idea of happy physical education teaching in basketball teaching of colleges. Journal of Anhui Sports Science, (1).

Guo, W. B. (2007). A study of the idea of happy physical education in basketball teaching. Journal of Harbin institute of physical education, (2).

Huang, X. Z. (2003, November). A discussion of happy physical education in colleges. Journal of xi 'an institute of physical education, 20(6).

Li, H. C. (n. d.). Basketball teaching and practice in colleges and universities.

Zhou, R. M. (1995). Teaching method of happy physical education in colleges and universities. Journal of Guangxi teachers college, (3).

\section{Copyrights}

Copyright for this article is retained by the author(s), with first publication rights granted to the journal.

This is an open-access article distributed under the terms and conditions of the Creative Commons Attribution license (http://creativecommons.org/licenses/by/3.0/). 